\title{
The iodine content of Norwegian foods and diets
}

\author{
Lisbeth Dahl ${ }^{1, *}$, Lars Johansson ${ }^{2}$, Kåre Julshamn $^{1}$ and Helle Margrete Meltzer ${ }^{3}$ \\ ${ }^{1}$ National Institute of Nutrition and Seafood Research (NIFES), PO Box 176 Sentrum, N-5804 Bergen, Norway: \\ ${ }^{2}$ Directorate for Health and Social Affairs, Oslo, Norway: ${ }^{3}$ Division of Environmental Medicine, Norwegian Institute \\ of Public Health, Oslo, Norway
}

Submitted 6 May 2003: Accepted 8 October 2003

\begin{abstract}
Objectives: To examine dietary iodine sources and to estimate the dietary iodine intake of the Norwegian population.

Design: Food iodine analyses carried out in Norway during the last 10 years were compiled, and iodine intake calculated on the basis of food intake data from nationwide dietary surveys among children and adults. The food intake of adults was measured by a self-administrated food-frequency questionnaire, which covered habitual diet during the past year. The food intake of children was measured by dietary record during four consecutive days.

Setting: Neither household nor industrial iodisation of salt is mandatory in Norway, but some brands of table salt have $5 \mu \mathrm{g}$ of iodine added per gram of $\mathrm{NaCl}$. In spite of this, the population has been considered iodine-replete for decades, i.e. having an iodine intake well above the Recommended Dietary Allowance of $150 \mu \mathrm{g} \mathrm{day}^{-1}$. This assumption has not been substantiated by dietary surveys.

Subjects: The adults included 1374 females and 1298 males aged 16-79 years. The children included 185 girls and 206 boys aged 4 years, 411 girls and 404 boys aged 9 years, and 517 girls and 492 boys aged 13 years.

Results: The calculated iodine intake was in the range of $100-250 \mu \mathrm{g} \mathrm{day}^{-1}$ in the majority of the adult population. The mean iodine intake was $136 \mu \mathrm{g} \mathrm{day}^{-1}$ $(170 \mu \mathrm{g} \mathrm{I} / 10 \mathrm{MJ})$ among women and $176 \mu \mathrm{g} \mathrm{day}^{-1}$ (161 $\left.\mu \mathrm{g} \mathrm{I} / 10 \mathrm{MJ}\right)$ among men. For children the iodine intake was in the range of $100-120 \mu \mathrm{gday}^{-1}$. Milk and dairy products contributed approximately $55 \%$ and $70 \%$ of the dietary iodine intake in adults and children, respectively. Fish contributed more than $20 \%$ of the iodine intake in adults and about $10 \%$ in children. The iodine contribution of drinking water was negligible.

Conclusions: While fish has the highest natural concentration of iodine and as such is an excellent iodine source, milk and diary products are the main determinants of iodine intake in the Norwegian population. Iodisation of cow fodder has been mandatory in Norway since 1950 and provides an efficient alternative to universal salt iodisation. Our results show that the dietary iodine intake of adults is in the range considered to be sufficient. The dietary intake of iodine was at recommended levels among the youngest children; however, it decreased among adolescents, especially among girls.
\end{abstract}

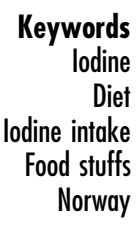

Iodine is an essential trace element required for normal activity of the thyroid hormones thyroxine and triiodothyronine. Clinical and sub-clinical manifestations of iodine deficiency, termed iodine deficiency disorders (IDD), affect all stages of human life and are characterised by a variety of conditions ${ }^{1,2}$. The disorders induced by iodine deficiency constitute a major nutritional problem worldwide and about 2.2 billion people in 130 countries are at risk of iodine deficiency ${ }^{3}$. To eliminate IDD the most common and widely used intervention is iodine fortification, using salt as the vehicle ${ }^{4}$.
The public health implications of iodine intake in Norway have moved from the historical problem of endemic goitre described in some parts of the country during the 1930s and 1940s to concerns about excessive iodine intake $e^{5,6}$. However, there has never been systematic monitoring of the iodine concentration of Norwegian foodstuffs or the iodine intake from a typical Norwegian diet. Studies performed in 1971-72 and 1985 in selected groups of Norwegians showed satisfactory iodine excretion in urine ${ }^{6}$. The contribution of iodised salt $(5 \mu \mathrm{g} \mathrm{I} / \mathrm{g} \mathrm{NaCl})$ is considered to be insignificant ${ }^{6}$ because 
only some brands of table salt are iodised and not industrial salt ${ }^{7}$. Cow fodder is controlled by legislation in Norway and since 1950 has had iodine (as KI) added the rate of $2 \mathrm{mg} \mathrm{I} / \mathrm{kg} \mathrm{NaCl}$ to protect the health of the animals ${ }^{8}$. This addition of iodine also results in higher iodine content in milk and dairy products. The maximum limit for iodine in fodder is set at $10 \mathrm{mg} \mathrm{I} / \mathrm{kg}$ in Norway ${ }^{8}$ and the European Union (EU). The best natural source of iodine is marine fish and other marine products?

In Norway, the recommended daily intake of iodine is $90 \mu \mathrm{g}$ for children aged 4-6 years, $120 \mu \mathrm{g}$ for children aged 7-10 years and $150 \mu \mathrm{g}$ for children older than 10 years and adults ${ }^{10}$. These recommendations are in line with those set by the World Health Organization (WHO) ${ }^{4}$. The lowest recommended daily intake of iodine is set at $70 \mu \mathrm{g}$ and the upper limit of intake is set at $1 \mathrm{mg}$ for adults in the Nordic countries ${ }^{11}$ and in the Recommended Dietary Allowances $^{12}$. The Scientific Committee on Food (SCF) of the EU has recently set the maximum intake of iodine to $600 \mu \mathrm{g}$ per day ${ }^{13}$.

To assess the dietary intake of iodine in a population and in subgroups of the population, reliable and accurate data of iodine concentrations of individual food items are needed. The aim of the present study was to estimate the iodine intake in the Norwegian population by using new data on the iodine concentration of foodstuffs and drinking water, and food intake data from representative samples of Norwegians. This allowed us to evaluate iodine intake in Norway in relation to recommended and upper levels of intake.

\section{Materials and methods}

\section{Samples and sampling}

Analyses of iodine in 1010 samples representing 102 different Norwegian foodstuffs during the last 10 years have been included in the present study. The majority of the analyses of iodine in fish fillets $(n=538)$ and milk and dairy products $(n=85)$ were reported by Julshamn et al. ${ }^{9}$ and Dahl et $a .^{14}$, respectively. Seventy-four iodine analyses of foodstuffs were listed in the Norwegian food composition table ${ }^{15}$ and the remaining 313 analyses of iodine have not been published earlier (Table 1).

The samples of foodstuffs included in the present study, with the exception of fish fillets ${ }^{9}$ and milk and dairy products ${ }^{14}$, were taken according to available production and marketing statistics for foodstuffs from various geographical areas, manufacturers, etc. Each composite sample included several sub-samples from various areas or manufacturers. When a particular manufacturer dominated the market, the composite sample from this manufacturer consisted of sub-samples from various production dates.

Twelve different meat and meat products were analysed for iodine, i.e. lamb, pork, beef, sausages, hamburgers, minced meat, grilled chicken and five different meat sandwich fillets. The iodine content of bread $(n=17)$, rice $(n=2)$, pasta $(n=2)$, beans $(n=1)$, peas $(n=1)$, biscuits $(n=5)$ and cereals products $(n=4)$ constitute the group of bread and cereals. Twenty different vegetables and eight different fruits and berries were included.

Table 1 lodine concentration of Norwegian foods: mean, minimum and maximum ( $n$ is the number of samples analysed)

\begin{tabular}{|c|c|c|c|c|c|c|}
\hline \multirow[b]{2}{*}{ Food group } & \multirow[b]{2}{*}{$n$} & \multicolumn{3}{|c|}{ lodine concentration $(\mu \mathrm{g} / 100 \mathrm{~g})$} & \multirow[b]{2}{*}{ Year of sampling } & \multirow[b]{2}{*}{ Reference } \\
\hline & & Mean & Minimum & Maximum & & \\
\hline Lean fish & 393 & 86 & 3 & 1270 & $1994-2000$ & $9, \neq \ddagger$ \\
\hline Fatty fish & 313 & 40 & 5 & 161 & $1995-2000$ & $9, \ddagger \ddagger$ \\
\hline Fish products & 44 & 59 & 8 & 176 & 1997, 2000, 2002 & 掊 \\
\hline Fish as sandwich spread* & 21 & 33 & 7 & 82 & 1997, 2000, 2002 & 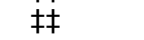 \\
\hline Other fish products $†$ & 17 & 12 & 3 & 36 & 1994,2000 & $\ddagger \ddagger$ \\
\hline Milk, all typesł & 70 & 15 & 2 & 37 & $2000 \dagger \dagger$ & 14,15 \\
\hline Yoghurt & 9 & 8 & 12 & 24 & $2000 \dagger \dagger$ & 14,15 \\
\hline Cream and cream products & 10 & 11 & 6 & 17 & $2000 \dagger \dagger$ & 14,15 \\
\hline Cheese, white & 20 & 38 & 13 & 75 & $2000 \dagger \dagger$ & 14,15 \\
\hline Cheese, whey & 11 & 129 & 10 & 200 & $2000 \dagger \dagger$ & 14,15 \\
\hline Eggs & $4 \S$ & 45 & 39 & 52 & 2000 & 拉 \\
\hline Meat and meat products & 12 & 2 & $<1$ & 7 & 2002 & $\ddagger \ddagger$ \\
\hline Bread and cereals & 32 & 3 & $<1$ & 9 & $1995-1997$ & 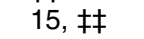 \\
\hline Potatoes & 49 & 2 & $<1$ & 4 & $1993-1995$ & $15, \ddagger \ddagger$ \\
\hline Vegetables & $24 \|$ & 2 & $<1$ & 5 & $1993-1995$ & 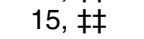 \\
\hline Fruits and berries & $8^{* *}$ & 2 & $<1$ & 4 & 1993-1995 & 15 , 㧊 \\
\hline Fats and oils & 3 & 2 & $<1$ & 6 & 2002 & 括 \\
\hline Water & 15 & 0.2 & 0.05 & 0.55 & 2002 & 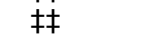 \\
\hline
\end{tabular}

* Mackerel in tomato sauce, sprat in tomato and in oil, pickled herring, caviar, smoked trout and mackerel, crab pâté and cod liver pâté. † Shrimp, freshwater trout and tuna canned in oil.

‡Full-fat milk, low-fat milk, extra low-fat milk, skimmed milk and curdled milk from summer and winter.

$\S$ Each sample consisted of 90 eggs.

I Three samples consisted of four sub-samples and one sample consisted of 25 sub-samples.

\| Each sample consisted of two to nine sub-samples.

** Each sample consisted of two to 17 sub-samples.

††Figures from the Norwegian food composition table ${ }^{15}$ were collected in 1995-2001.

㧊 Not published earlier. 
Drinking water (tap water) samples were collected from 15 different locations in Norway by the Norwegian Food Control Authority. The water samples were collected in August 2002 in Vadsø, Kautokeino, Alta, Troms $\varnothing$, Bodø, Mosjøen, Trondheim, Ålesund, Hamar, Gol, Rjukan, Oslo, Kristiansand, Stavanger and Bergen. The water samples were collected in clean glass containers, after allowing the water to run for 5 to $10 \mathrm{~s}$. Samples were sent to our laboratory and stored at $4{ }^{\circ} \mathrm{C}$ until analysis.

\section{Chemical analysis and analytical quality control}

The iodine concentrations in the foodstuffs and drinking water were determined by inductively coupled plasmamass spectrometry ${ }^{9,16}$. The 35 samples of milk and dairy products reported in the Norwegian food composition table ${ }^{15}$ were analysed for their iodine content by neutron activation analysis. The limit of detection (LOD), calculated according to the three-sigma criterion, was estimated from the variance of the analytical blank values $(n=20)$. The LOD was estimated to be $0.06 \mathrm{ng} \mathrm{ml}^{-1}$. The limit of quantification (LOQ), calculated according to the three-sigma criterion, was estimated to $15 \mathrm{ngg}^{-1}$ (dry mass) when $0.2 \mathrm{~g}$ of sample was used for analysis, and with a dilution factor of 50 . This corresponds to a LOQ of approximately $2-4 \mu \mathrm{g} \mathrm{kg}^{-1}$ (wet weight).

\section{Study population}

Food intake among adults was derived from a representative nation-wide dietary survey of 1374 women and 1298 men aged 16-79 years in March, June, September and November 1997 (Norkost 1997) ${ }^{17}$.

Food intake of children was derived from representative nation-wide dietary surveys of children aged 4, 9 and 13 years conducted during 2000-01 (Ungkost-2000) ${ }^{18,19}$. The 4-year-old children participated in a survey performed from August to December 2001 ${ }^{18}$. Data from 206 boys and 185 girls are included in the present study. Dietary surveys among nation-wide and representative samples of 4th graders (9 years) and 8th graders (13 years) were conducted in August to December $2000^{19}$. Data from 404 boys and 411 girls aged 9 years and 492 boys and 517 girls aged 13 years are included in the present study.

\section{Food intake}

Food intake among adults was measured by a selfadministrated food-frequency questionnaire (FFQ). The frequency of intake was reported per day, week or month depending on which kind of food was asked about. The portions were reported as pieces, glasses, cups, decilitres or spoons. The FFQ was supposed to cover the habitual diet during the past year and included questions about how often and how much was eaten of approximately 180 foods and dishes. The FFQ has been validated ${ }^{20-23}$. Further details and results from the Norkost 1997 survey have been published elsewhere ${ }^{17}$.
The food intake of children was reported for four consecutive days in a pre-coded diary with lists of the most common foodstuffs and beverages in Norway. In addition, open lines to register the intakes of food items and beverages not mentioned in the list were included in the diary. The portion size was given as units, e.g. beverages was given as number of glasses. A book with pictures of different sizes of glass, thickness of slices of bread and portion sizes of different meals was enclosed with the diary. Further details and results of the Ungkost-2000 survey have been published elsewhere ${ }^{18,19}$.

\section{Iodine intake}

Iodine intake was calculated on the basis of the food intake of each adult participant. The mean food intake and the iodine intake are reported, as well as percentiles for iodine intake among adults. For children the iodine intake was calculated on the basis of the mean food intake for boys and girls separately in each age group. The mean iodine concentration of the food groups given in Table 1 was used in the calculations. The iodine content of water (1.7 $\mu \mathrm{gl}^{-1}$ ) was used to calculate the iodine contribution from all beverages based on the findings by Rasmussen et $a l^{24}$ and Pedersen et al. ${ }^{25}$.

\section{Results}

\section{Iodine concentrations of Norwegian foods}

The average and range of iodine concentration found in each food group are listed in Table 1. In general, the highest average iodine concentrations were found in the food groups fish, milk and eggs. The average iodine content of lean fish was generally more than twice that of fatty fish. Several processed fish products were also rich in iodine. The average iodine concentration in all types of milk produced in the summer was $83 \mu \mathrm{gl}^{-1}$ and $212 \mu \mathrm{gl}^{-1}$ in milk produced in the winter. No differences were found between average iodine content within the same season for the different types of milk analysed, e.g. skimmed milk versus full-fat milk. The average iodine concentration of all milk during the year was used in the present study. The iodine concentration in the different types of cheese did not vary with the fat content. The concentration range of iodine in white cheese and whey cheese indicated the influence of the seasonal variation in the milk used.

Table 2 shows the iodine concentrations in drinking water at different locations in Norway. The iodine concentrations of drinking water sampled along the coast were higher $\left(2.0 \mu \mathrm{gl}^{-1}\right)$ compared with drinking water sampled from inland areas $\left(0.8 \mu \mathrm{gl}^{-1}\right)$. The average iodine content in water of $1.7 \mu \mathrm{gl}^{-1}$ was used in the present study to calculate the iodine intake from beverages.

\section{Dietary iodine intake}

The daily intake of foodstuffs and the calculated intake of iodine for men and women are given in Table 3. The mean 
Table 2 lodine concentration $\left(\mu \mathrm{gl}^{-1}\right)$ in drinking water in Norway: mean (standard deviation)

\begin{tabular}{lc}
\hline Location $^{*}$ & lodine $\left(\mu \mathrm{gl}^{-1}\right)$ \\
\hline Coast & $2.0(1.5)$ \\
Vadsø & 0.8 \\
Alta & 1.2 \\
Troms & 0.5 \\
Bodø & 1.4 \\
Mosjøen & 0.8 \\
Trondheim & 1.9 \\
Allesund & 2.1 \\
Bergen & 2.3 \\
Stavanger & 5.5 \\
Kristiansand & 4.2 \\
Oslo & 1.5 \\
Inland & $0.8(0.2)$ \\
Kautokeino & 0.9 \\
Hamar & 0.9 \\
Gol & 0.7 \\
Rjukan & 0.6 \\
All & $1.7(1.4)$ \\
\hline
\end{tabular}

* Location gradient from north to south.

intake of iodine was $176 \mu \mathrm{gday}^{-1}$ in men and $136 \mu \mathrm{g} \mathrm{day}^{-1}$ in women. The mean energy intake was 10.9 and $8.0 \mathrm{MJ} \mathrm{day}^{-1}$ in men and women ${ }^{17}$, respectively. The iodine intake in men corresponds to $161 \mu \mathrm{g} / 10 \mathrm{MJ}$ and in women to $170 \mu \mathrm{g} / 10 \mathrm{MJ}$. Milk and dairy products and fish and fish products were the main sources of iodine, contributing $80 \%$ of the iodine intake. The other food groups contributed very small amounts of iodine to the dietary intake of the nutrient, except for eggs, which contributed a relatively high percentage of iodine considering the small amount eaten.
Table 4 Intake of iodine by Norwegian adults*

\begin{tabular}{lccc}
\hline & \multicolumn{3}{c}{ lodine intake $\left(\mu \mathrm{g} \mathrm{day}^{-1}\right)$} \\
\cline { 2 - 4 } Percentile & $\begin{array}{c}\text { Men } \\
(n=1298)\end{array}$ & $\begin{array}{c}\text { Women } \\
(n=1374)\end{array}$ & $\begin{array}{c}\text { All } \\
(n=2672)\end{array}$ \\
\hline 5 & 72 & 58 & 63 \\
10 & 89 & 71 & 78 \\
25 & 121 & 96 & 105 \\
50 & 166 & 129 & 146 \\
75 & 219 & 168 & 191 \\
90 & 274 & 206 & 246 \\
95 & 315 & 236 & 283 \\
\hline
\end{tabular}

${ }^{*}$ Food intake data from the Norkost 1997 survey ${ }^{17}$.

The percentiles of iodine intake for men and women are given in Table 4 . About $7-8 \%$ of adults had an estimated dietary iodine intake less than $70 \mu \mathrm{g} \mathrm{day}^{-1}$. Only 17 subjects $(0.6 \%)$ had an estimated dietary iodine intake exceeding $400 \mu \mathrm{g} \mathrm{day}^{-1}$ and the highest single estimated intake of iodine was $616 \mu \mathrm{g} \mathrm{day}^{-1}$.

The mean daily intake of iodine among the groups of children ranged from 90 to $121 \mu \mathrm{g}$ (Table 5). Milk and dairy products contributed approximately $64-71 \%$ of the total iodine intake, and fish and fish products contributed $12-14 \%$ of the total iodine intake in the diet of the children. Milk was the most important source of iodine in the children's diet, contributing approximately $50 \%$ of the total iodine intake. The lowest iodine intake was found among girls aged 13 years and this was due to a lower intake of milk compared with the other age groups of children. Boys aged 9 years had the highest intake of milk and also the highest intake of iodine.

Table 3 Daily intakes of food and iodine from different food groups by Norwegian adults

\begin{tabular}{|c|c|c|c|c|c|c|}
\hline \multirow[b]{2}{*}{ Food } & \multicolumn{2}{|c|}{$\begin{array}{l}\text { Mean food intake* } \\
\left(\mathrm{g} \mathrm{day}^{-1}\right)\end{array}$} & \multicolumn{2}{|c|}{$\begin{array}{l}\text { lodine intake† } \\
\left(\mu \text { day }^{-1}\right)\end{array}$} & \multicolumn{2}{|c|}{$\begin{array}{c}\text { Proportion of intake } \\
(\%)\end{array}$} \\
\hline & Men & Women & Men & Women & Men & Women \\
\hline Fish, total & 72 & 58 & 40 & 33 & 23 & 24 \\
\hline Fish, lean & 26 & 21 & 22 & 18 & & \\
\hline Fish, fatty & 11 & 8 & 4 & 3 & & \\
\hline Fish products & 14 & 12 & 8 & 7 & & \\
\hline Fish, sandwich spread & 12 & 8 & 4 & 3 & & \\
\hline Fish, other products & 10 & 9 & 1 & 1 & & \\
\hline Dairy products & 577 & 416 & 101 & 76 & 57 & 56 \\
\hline Milk, all types $\ddagger$ & 518 & 363 & 78 & 54 & & \\
\hline Cheese, white & 23 & 22 & 9 & 8 & & \\
\hline Cheese, whey & 9 & 8 & 12 & 11 & & \\
\hline Cream and cream products & 27 & 23 & 3 & 2 & & \\
\hline Eggs & 19 & 15 & 9 & 7 & 5 & 5 \\
\hline Meat and meat products & 125 & 87 & 3 & 2 & 2 & 1 \\
\hline Bread and cereals & 317 & 227 & 9 & 6 & 5 & 4 \\
\hline Potatoes & 147 & 100 & 3 & 2 & 2 & 1 \\
\hline Vegetables & 123 & 146 & 3 & 3 & 2 & 2 \\
\hline Fruits, berries and juice & 218 & 225 & 4 & 5 & 2 & 4 \\
\hline Fats and oils & 42 & 28 & 1 & 1 & 1 & 1 \\
\hline Beverages & 1512 & 1370 & 3 & 3 & 2 & 2 \\
\hline Total intake & & & 176 & 136 & & \\
\hline
\end{tabular}

* Food intake data from the Norkost 1997 survey ${ }^{17}$

† Mean iodine concentrations are given in Table 1.

$\ddagger$ Includes yoghurt. 
Table 5 Intake of iodine from different food groups among Norwegian children*

\begin{tabular}{|c|c|c|c|c|c|c|}
\hline \multirow[b]{3}{*}{ Food } & \multicolumn{6}{|c|}{ lodine intake $\left(\mu\right.$ g day $\left.^{-1}\right)$} \\
\hline & \multicolumn{2}{|c|}{ 4-year-olds } & \multicolumn{2}{|c|}{ 9-year-olds } & \multicolumn{2}{|c|}{ 13-year-olds } \\
\hline & $\begin{array}{c}\text { Girls } \\
(n=185)\end{array}$ & $\begin{array}{c}\text { Boys } \\
(n=206)\end{array}$ & $\begin{array}{c}\text { Girls } \\
(n=411)\end{array}$ & $\begin{array}{c}\text { Boys } \\
(n=404)\end{array}$ & $\begin{array}{c}\text { Girls } \\
(n=517)\end{array}$ & $\begin{array}{c}\text { Boys } \\
(n=492)\end{array}$ \\
\hline Fish and fish products & 12 & 14 & 13 & 14 & 11 & 14 \\
\hline Milk and dairy products & 70 & 70 & 67 & 85 & 59 & 70 \\
\hline Eggs & 4 & 5 & 4 & 5 & 4 & 5 \\
\hline Meat and meat products & 1 & 1 & 2 & 2 & 2 & 3 \\
\hline Bread and cereals & 5 & 5 & 7 & 8 & 7 & 9 \\
\hline Vegetables and fruits & 5 & 5 & 6 & 6 & 6 & 6 \\
\hline Fats and oils & 0 & 0 & 0 & 0 & 0 & 0 \\
\hline Beverages & 1 & 1 & 1 & 1 & 1 & 2 \\
\hline Total & 98 & 101 & 100 & 121 & 90 & 109 \\
\hline
\end{tabular}

*Based on mean food intake from the Ungkost-2000 survey ${ }^{18,19}$.

\section{Discussion}

The present study has compiled the concentrations of iodine in Norwegian foodstuffs and is the first study to provide information on the dietary intake of iodine based on food consumption data in representative samples of the Norwegian population. Determination of the iodine content in foodstuffs, summarised in the present study, shows that fish and fish products, milk and dairy products and eggs have the highest iodine concentrations of the foodstuffs analysed. In addition, the study shows that the iodine concentration of drinking water is very low $\left(0.2 \mu \mathrm{gl}^{-1}\right)$ in Norway.

The iodine concentration in drinking water differed approximately 10 -fold among the sampling sites in Norway. Similar geographical variation in the iodine content of tap water has been found in Finland ${ }^{26}$, Germany $^{27}$ and Denmark ${ }^{24,25,28}$. In Denmark, the iodine concentration of tap water has been shown to be of considerable importance for regional differences in iodine intake $^{25}$. However, even if the drinking water from the area with the highest iodine concentration $\left(5.5 \mu \mathrm{gl}^{-1}\right)$ had been used in the calculations of the present study, beverages would have contributed less than $10 \mu \mathrm{g}$ of iodine per day, taking into account that the intake of beverages is about $1500 \mathrm{ml}$ daily ${ }^{17}$.

The mean dietary intake of iodine based on the FFQ covering the habitual diet was within the recommendation for men $\left(176 \mu \mathrm{g} \mathrm{day}^{-1}\right)$, while the mean dietary intake of iodine among women (136 $\left.\mu \mathrm{g} \mathrm{day}^{-1}\right)$ was slightly below the recommendation of $150 \mu \mathrm{g} \mathrm{day}^{-1}$ for adults. However, the intake of iodine in relation to energy intake ( $\mu \mathrm{g} \mathrm{I} / 10 \mathrm{MJ})$ was higher in women $(170 \mu \mathrm{g} / 10 \mathrm{MJ})$ than in men $(161 \mu \mathrm{g} / 10 \mathrm{MJ})$. Only a minor percentage of the adult population had a daily intake of iodine below the lowest recommended intake of $70 \mu \mathrm{g} \mathrm{day}^{-1}$. The food intakes of these subjects were probably underestimated, as the daily energy intake was about $3 \mathrm{MJ}$ below the mean energy intake of all subjects in the study. Furthermore, the present study shows that none of the adults had an intake of iodine above the maximum safe intake level of $1 \mathrm{mg} \mathrm{day}^{-1}$ set by the Nordic countries ${ }^{11}$. The 95 th percentile of iodine intake in adults was approximately half the tolerable upper intake level of iodine recently set by the SCF in the $\mathrm{EU}^{13}$. In fact, only one subject had a daily intake of iodine slightly above $600 \mu \mathrm{g}$.

The intakes of iodine among 4-year-old girls (98 $\mu \mathrm{g} \mathrm{day}^{-1}$ ) and boys $\left(101 \mu \mathrm{g} \mathrm{day}^{-1}\right)$ were above the recommended intake of $90 \mu \mathrm{g} \mathrm{day}^{-1}$. For children aged 9 years, mean dietary intake of iodine of the boys $\left(121 \mu \mathrm{g} \mathrm{day}^{-1}\right)$ was at the same level as the recommendation $^{10}$, but in girls the mean dietary iodine intake $\left(100 \mu \mathrm{g} \mathrm{day}^{-1}\right)$ was below the recommendation of $120 \mu \mathrm{g} \mathrm{day}^{-1}$. The mean iodine intake in girls $\left(90 \mu \mathrm{g} \mathrm{day}^{-1}\right)$ and boys $\left(109 \mu \mathrm{g} \mathrm{day}^{-1}\right)$ aged 13 years was below the recommendation set at $150 \mu \mathrm{g} \mathrm{day}^{-1}$. The lower iodine intake in 13-year-old girls can be explained by a lower intake of milk.

Since the iodine content of foodstuffs varies considerably, with relatively few foods having a high content of iodine, the intake of iodine will vary greatly from day to day within a population ${ }^{29,30}$. The seasonal variation in iodine concentration of Norwegian milk ${ }^{14}$ will give a $20 \%$ lower iodine intake during the summer than during the winter among adults in the present study, assuming small variation in the intake of milk during the year. Seasonal variation of iodine intake from milk is described in other countries where milk and dairy products are one of the main contributors to the total iodine intake ${ }^{31,32}$. In Denmark both seasonal and geographical variations in iodine intake were found ${ }^{29}$.

When assessing the iodine status by estimating the iodine intake in the diet, all major iodine sources need to be taken into consideration ${ }^{33}$. The present study has not considered the contribution of iodine from supplements, the contribution from iodised salt or the intake of seaweed. Data from the Norkost 1997 survey $^{17}$ show that $37 \%$ of men and $59 \%$ of women used vitamin and/or mineral supplements. The data for children showed that fewer than $10 \%$ of them used supplements that may 
contain iodine ${ }^{18,19}$. There is no documentation as to what extent and in what amount the vitamin and mineral supplements contain iodine in Norway. However, it is reasonable to assume that about $25 \%$ of the most commonly used vitamin and mineral supplements contain 70 to $150 \mu \mathrm{g}$ I per tablet. When it comes to iodised salt, only some brands of table salt are fortified with iodine, and regulations permit only the addition of $5 \mu \mathrm{g}$ of iodine per $g$ of $\mathrm{NaCl}^{7}$. Thus iodised salt will add only about $15 \mu \mathrm{g} \mathrm{day}{ }^{-1}$ to our intake of iodine if $3 \mathrm{~g}$ of iodised table salt is used daily. Industrial salt used in food production is not supplemented with iodine ${ }^{7}$. The intake of seaweed in Norway is unknown, but consumption is expected to be restricted to small subgroups of the population.

The daily intake of iodine by adults in other countries has recently been calculated by different dietary methods. In Denmark, the median daily intake of iodine was in the range of $85-168 \mu \mathrm{g}$ in different groups of the population $^{29}$. The daily intake of iodine has been calculated in several studies in The Netherlands and found to be in the range of $85-293 \mu \mathrm{g}^{34}$. The mean intake of iodine is calculated to be approximately $340 \mu \mathrm{g} \mathrm{day}^{-1}$ in Finland ${ }^{31}$ and $119 \mu \mathrm{g} \mathrm{day}^{-1}$ in Germany ${ }^{35}$. In the UK the daily iodine intake was found to be in the range of $166-277 \mu \mathrm{g}$ in studies carried out from 1985 to $1997^{36-38}$. The intake of iodine in The Netherlands ${ }^{34}$ of boys and girls aged 4-6 years was similar to those found in the present study, whereas the intake of iodine in children and adolescents aged $7-15$ years was higher compared with findings in the present study.

The WHO/International Council for Control of Iodine Deficiency Disorders/United Nations Children's Fund criterion for assessing iodine status is the iodine concentration in urine $e^{4}$. Iodine intake assessed in studies performed in $1971-72^{6}$ and $1985^{6}$ in several selected groups of Norwegians showed mean urinary iodine excretion in the range of $173-260 \mu \mathrm{g} / 24 \mathrm{~h}$, which indicates sufficient intake of iodine. A recent study of two selected groups of Norwegians ${ }^{39}$ showed median urinary iodine excretion of 117 and $85 \mu \mathrm{gl}^{-1}$, indicating sufficient iodine intake and mild deficiency, respectively. The urinary iodine excretion of more than half of the population of Western and Central Europe indicates that they are at risk of iodine deficiency ${ }^{40}$.

According to Vitti et $a l^{41}$, most nations of Western and Central Europe have weak or non-existent governmental programmes to address the risk of iodine deficiency. Universal salt iodisation is the agreed strategy for achieving iodine sufficiency world-wide ${ }^{4}$. Although Norway has never had mandatory iodisation of salt, iodine deficiency has disappeared. The increase in the iodine content of milk and related dairy products through fodder fortification, and also the more widespread use of saltwater fish, explains the eradication of endemic goitre in Norway 5,6 . The present study shows clearly that the iodine fortification of cow fodder is of importance for the iodine intake of Norwegians, and the fortification of cow fodder seems to be an effective way to provide a population with sufficient iodine. Other studies have claimed that iodine may occur in milk as a result of the use of iodophores as cow teat sterilisers and equipment sanitisers ${ }^{42,43}$. The dairies in Norway do not use sanitisers or disinfectants containing iodophores ${ }^{14}$. In Britain, the eradication of endemic goitre was mainly due to changes in farming practices of milk and the marketing of milk ${ }^{44}$. The more widespread use of fortified fodder in Northern Europe compared with Southern Europe, where pasture feeding is available for a greater part of the year, may therefore explain why countries in Northern Europe are likely to be more iodine-sufficient compared with countries in Southern Europe.

The importance of milk and fish for total iodine intake found in the present study may put certain groups of the population at risk of low intake of iodine, i.e. subjects with allergy to milk or fish, vegetarians who do not consume fish, milk and dairy products and others with a low consumption of milk and fish. Results from two different studies in the $\mathrm{UK}^{45,46}$ indicated that different vegetarian diets supplied less iodine than non-vegetarian diets.

In conclusion, milk, dairy products and fish are the main sources of iodine in the Norwegian diet. The iodine contribution of drinking water is negligible. The calculated iodine intake based on an FFQ covering the habitual diet showed that iodine intake was in the range of 100$250 \mu \mathrm{g} \mathrm{day}^{-1}$ in the majority of the adult population. The dietary intake of iodine was at the recommended level for the youngest children; however, it decreased among adolescents, especially girls. The study verifies the importance of a regular intake of milk and dairy products, as well as seafood, to meet the requirement for iodine in the diet.

\section{Acknowledgements}

Berit Engen Solli and Jan Brenna at NIFES are acknowledged for skilful technical assistance with the iodine analyses. Employees at the Norwegian Food Control Authority are kindly thanked for collecting the water samples. The Norwegian Research Council (NFR) is thanked for financially supporting this work (Project no. 120824/112)

\section{References}

1 Hetzel BS. Iodine deficiency disorders (IDD) and their eradication. Lancet 1983; ii: $1126-9$.

2 Delange $\mathrm{F}$. The disorders induced by iodine deficiency. Thyroid 1994; 4: 107-28.

3 Hetzel BS. Eliminating iodine deficiency disorders - the role of the International Council in the global partnership. Bulletin of the World Health Organization 2002; 80(5): $410-3$.

4 World Health Organization (WHO)/United Nations Children's Fund/International Council for Control of Iodine 
Deficiency Disorders. Assessment of the Iodine Deficiency Disorders and Monitoring their Elimination. A Guide for Programme Managers, 2nd ed. WHO/NHD/01.1. Geneva: WHO, 2001

5 Devold O, Batt F, Closs K, Backer J. En strumaundersøkelse fra Modum. Norsk Magasin for Lagevitenskap 1937; 7: 900-37 [in Norwegian].

6 Frey H, Rosenlund B, Try K, Theodorsen L. Urinary excretion of iodine in Norway. Delange F, ed. Iodine Deficiency in Europe. New York: Plenum Press, 1993; 297-300.

7 Ministry of Health. Generell forskrift for produksjon og frambud m.v. av noeringsmidler [Regulation of General Production of Food Offered to Consumers, online], 2002. Available at http://www.snt.no/rettsregler/forskrifter/ hd-19830708-1252.html [in Norwegian].

8 Ministry of Agriculture. Forskrift om fôrvarer [Regulation of Feeding Stuff, online], 2002. Available at from http://www. lovdata.no/for/sf/ld/ld-20021107-1290.html [in Norwegian].

9 Julshamn K, Dahl L, Eckhoff K. Determination of iodine in seafood by inductively coupled plasma/mass spectrometry. Journal of AOAC International 2001; 84: 1976-83.

10 National Council on Nutrition and Physical Activity. Norske noeringsstoffanbefalinger [Norwegian Nutrient Recommendations]. Oslo: National Council on Nutrition and Physical Activity, 1997 [in Norwegian].

11 Sandström B, Aro A, Becker W, Lyhne N, Pedersen JI, Pórsdóttir I. Nordiska närings-rekommendationer 1996 [Nordic Nutrition Recommendations 1996]. Nord 1996; 28. Copenhagen: Nordic Council of Ministers, 1996 [in Swedish].

12 Subcommittee of the Tenth Edition of the RDAs, Food and Nutrition Board Commission on Life Sciences, National Research Council. Iodine. In: Recommended Dietary Allowances. Washington, DC: National Academy Press, 1989; 213-6.

13 European Commission. Opinion of the Scientific Committee on Food on the Tolerable Upper Intake Level of Iodine [online]. Available at http://europa.eu.int/comm/ food/fs/sc/scf/out146_en.pdf. Accessed 7 October 2002.

14 Dahl L, Opsahl JA, Meltzer HM, Julshamn K. Iodine concentration in Norwegian milk and dairy products. British Journal of Nutrition 2003; 90: 679-85.

15 Rimestad AH, Borgejordet A, Norunn KV, Sygnestveit K, Løken EB, Trygg K, et al. Den store matvaretabellen [Norwegian Food Composition Table]. Oslo: Gyldendal undervisning, 2001 [in Norwegian].

16 Fecher PA, Goldmann I, Nagengast A. Determination of iodine in food samples by inductively coupled plasma mass spectrometry after alkaline extraction. Journal of Analytical Atomic Spectrometry 1998; 13: 977-82.

17 Johansson L, Solvoll K. Norkost 1997. Landsomfattende kostholdsundersøkelse blant menn og kvinner $i$ alderen 16-79 àr [National Dietary Survey among Males and Females, 16-79 years]. Publication No. 2. Oslo: National Council on Nutrition and Physical Activity, 1999 [in Norwegian].

18 Pollestad M, Øverby N, Andersen L. Ungkost-2000. Kosthold blant 4-åringer: Landsomfattende kostholdsundersøkelse [Dietary Intake among 4 years old Children]. Oslo: Directorate for Health and Social Affairs, Division of Nutrition, 2002 [in Norwegian].

19 Øverby N, Andersen L. Ungkost-2000: Landsomfattende kostholdsundersøkelse blant elever $i$ 4-og 8. klasse $i$ Norge [National Dietary Survey among 4- and 8-grade Pupils in Norway]. Oslo: Directorate for Health and Social Affairs, Division of Nutrition, 2002 [in Norwegian].

20 Nes M, Frost Andersen L, Solvoll K, Sandstad B, Hustvedt B, Løvø A, et al. Accuracy of a quantitative food frequency questionnaire applied in elderly Norwegian women. European Journal of Clinical Nutrition 1992; 42: 809-21.

21 Solvoll K, Lund-Larsen K, Søyland E, Sandstad B, Drevon C.
A quantitative food frequency questionnaire evaluated in a group of dermatologic outpatients. Scandinavian Journal of Nutrition 1993; 37: 150-5.

22 Andersen LF, Solvoll K, Drevon C. Very long-chain $n-3$ fatty acids as biomarkers for intake of fish and $n-3$ fatty acids concentrates. American Journal of Clinical Nutrition 1996; 64: 305-11

23 Andersen LF, Solvoll K, Johansson LRK, Salminen I, Aro A, Drevon CA. Evaluation of a food frequency questionnaire with weighed records, fatty acids and alpha-tocopherol in adipose tissue and serum. American Journal of Epidemiology 1999; 150: 75-87.

24 Rasmussen LB, Larsen EH, Ovesen L. Iodine content in drinking water and other beverages in Denmark. European Journal of Clinical Nutrition 2000; 54: 57-60.

25 Pedersen KM, Laurberg P, Nøhr S, Jorgensen A, Andersen S. Iodine in drinking water varies by more than 100 -fold in Denmark. Importance for iodine content of infant formulas. European Journal of Endocrinology 1999; 140: 400-3.

26 Häsänen E. Iodine content of drinking water and diseases of circulatory system. Annales Medicinae Experimentalis et Biologiae Fenniae 1970; 48: 117-21.

27 Felgentraeger HJ. Zum jodgehaltes der umwelt in der DDR und seine beziehungen zum gesundheitzustand der bevolkerung. Zeitschrift für die gesamte Hygiene und ibre Grenzgebiete 1984; 30: 154-5 (in German).

28 Andersen S, Petersen SB, Laurberg P. Iodine in drinking water in Denmark is bound in humic substances. European Journal of Endocrinology 2002; 147: 663-70.

29 Rasmussen LB, Ovesen L, Bülow I, Jørgensen T, Knudsen N, Laurberg $\mathrm{P}$, et al. Dietary iodine intake and urinary iodine excretion in a Danish population: effect of geography, supplements and food choice. British Journal of Nutrition 2002; 87: 61-9.

30 Wild CP, Andersson C, O'Brien NM, Wilson L, Woods JA. A critical evaluation of the application of biomarkers in epidemiological studies on diet and health. British Journal of Nutrition 2001; 86: S37-53.

31 Varo P, Saari E, Koivistoinen P. Iodine in Finnish foods. International Journal for Vitamin and Nutrition Research 1982; 52: 80-9.

32 Ministry of Agriculture, Fisheries and Food. Iodine in Milk [online]. Food Surveillance Information Sheet No. 196, 2000. Available at http://www.food.gov.uk/science/surveillance/ maffinfo/2000/maff-2000-198.

33 Tokudome S, Tokudome Y, Moore MA. Dietary iodine sources other than fish. European Journal of Clinical Nutrition 2002; 56: 467-8.

34 Brussaard JH, Hulshof K, Lowik MRH. Calculated iodine intake before and after simulated iodization (Dutch Nutrition Surveillance System). Annals of Nutrition \& Metabolism 1995; 39: 85-94.

35 Manz F, Böhmer T, Gärtner R, Grossklaus R, Klett M, Schneider R. Quantification of iodine supply: representative data on intake and urinary excretion of iodine from the German population in 1996. Annals of Nutrition $\mathcal{E}$ Metabolism 2002; 46: 128-38.

36 Lee SM, Lewis J, Buss DH, Holcombe GD, Lawrance PR. Iodine in British foods and diets. British Journal of Nutrition 1994; 72: 435-46.

37 Rose M, Miller P, Baxter M, Appleton G, Crews H, Croasdale M. Bromine and iodine in 1997 UK total diet study samples. Journal of Environmental Monitoring 2001; 3: 361-5.

38 Ministry of Agriculture, Fisheries and Food (MAFF). Nutrient Analysis of Liquid Pasteurised Milk. Food Surveillance Information Sheet No. 128. London: HM Stationery Office, 1997.

39 Dahl L, Meltzer HM, Opsahl JA, Julshamn K. Iodine intake and status in two groups of Norwegians. Scandinavian Journal of Nutrition 2003; 47(4): 170-8. 
40 Vitti P, Rago T, Aghini-Lombardi F, Pinhera A. Iodine deficiency in Europe. Public Health Nutrition 2001; 4: 529-35.

41 Vitti P, Delange F, Pincherra A, Zimmermann M, Dunn JT Europe is iodine deficient [correspondence]. Lancet 2003; 361: 1226.

42 Franke PA, Goldman I, Osland RB. Factors affecting iodine concentration of milk of individual cows. Journal of Dairy Science 1983; 66: 997-1002.

43 Galton DM, Peterson LG, Erb HM. Milk iodine residues in herds practicing iodophors premilking teat disinfection. Journal of Dairy Science 1986; 69: 267-71.
44 Phillips DIW. Iodine, milk and the elimination of endemic goitre in Britain: the story of an accidental public health triumph. Journal of Epidemiology and Community Health 1997; 51: 391-3.

45 Lightowler HJ, Davies GJ. Iodine intake and iodine deficiency in vegans as assessed by the duplicate-portion technique and urinary iodine excretion. British Journal of Nutrition 1998; 80: 529-35.

46 Remer T, Neubert A, Manz F. Increased risk of iodine deficiency with vegetarian nutrition. British Journal of Nutrition 1999; 81: 45-9. 